\title{
A PERCEPÇÃO DOS JUÍZES PAULISTANOS ACERCA DA ATUAÇÃO DO PERITO CONTADOR ASSISTENTE À LUZ DO CÓDIGO DE PROCESSO CIVIL
}

\author{
Giancarlo Zannon 1 \\ Ivam Ricardo Peleias 2 \\ Elionor Farah Jreige Weffort 3 \\ Mônica Bonetti Couto 4
}

- Artigo recebido em: 01/09/2017 -- Artigo aceito em: 12/08/2018 --' Segunda versão aceita em: 25/08/2018

\section{RESUMO}

Uma consequência da maior inadimplência é o aumento das ações judiciais revisionais e de execução, situação que pode requerer a perícia contábil para subsidiar o processo decisório dos juízes. No poder judiciário, a prova pericial contábil pode ser produzida pelo perito nomeado pelo juiz ou pelos peritos assistentes contratados pelas partes. Esta pesquisa buscou analisar a percepção de juízes sobre a atuação do perito contador assistente, também conhecido por assistente técnico, em especial quanto ao parecer pericial contábil como meio para o convencimento motivado e auxílio no julgamento. É uma pesquisa qualitativa e descritiva, na qual foram entrevistados treze juízes da esfera Cível de $1^{a}$ instância na cidade de São Paulo. As falas obtidas foram avaliadas com a aplicação das técnicas de Análise de Conteúdo e Dialético-Hermenêutica. Foram identificadas três categorias nos discursos dos entrevistados, que favorecem, desfavorecem ou contribuem para a atuação do perito contador assistente. Os entrevistados entendem que a atuação do perito contador assistente é relevante para o convencimento motivado e julgamento da causa e que o parecer pericial contábil pode ser usado para fundamentar o processo decisório do juiz, bem como, sua ausência pode prejudicar o julgamento e comprometer o capital jurídico. Para os entrevistados é relevante a atuação dos peritos contadores assistentes, mas existe a necessidade de aprimorarem o seu conhecimento jurídico, linguístico, experiência processual, além de uma postura

1 Mestre em Ciências Contábeis pela Fecap - Fundação Escola de Comércio Álvares Penteado, Avenida Liberdade, 532 - Liberdade - CEP 01502-001 - SãoPaulo - SP - telefone: 11-3272-2301 - giancarlo@zannoncontadores.com.br-

2 Doutor e Mestre em Ciências Contábeis pela FEA-USP, Professor e Pesquisador Contábil da Fecap - Fundação Escola de Comércio Álvares Penteado, Avenida Liberdade, 532 Liberdade - CEP 01502-001 - São Paulo, SP - telefone: 11-3272-2301 - ivamrp@fecap.br.

3 Doutora em Controladoria e Contabilidade pela FEA-USP, Professora e Pesquisadora Contábil da Fecap - Fundação Escola de Comércio Álvares Penteado, Avenida Liberdade, 532 - Liberdade - CEP 01502-001 - São Paulo, SP - telefone: 11-3272-2301 - eweffort@fecap.br.

${ }^{4}$ Monica Bonetti Couto, Doutora e Mestra em Direito pela Pontifícia Universidade Católica de São Paulo - PUC/SP, Professora da Escola Paulista de Direito, Avenida Liberdade, 956 Liberdade, São Paulo - SP, $01502-001$ - email: monicabonetticouto@yahoo.com.br 
mais técnica e imparcial, para que seu trabalho seja melhor compreendido e mais bem aproveitado.

Palavras-chave: Prova pericial, perito contador assistente, cognição judicial.

\title{
THE PERCEPTIONS OF JUDGES IN SAO PAULO CITY ABOUT THE EXPERT ACCOUNTANT ASSISTANT ROLE CONCERNING THE BRAZILIAN CODE OF CIVIL PROCEDURE
}

\begin{abstract}
A consequence of higher insolvency is the increase in revision and execution judicial proceedings, a situation that may require the accounting expert to subsidize the decision-making process of the judges. In the Judiciary, the accounting proof can be produced both by an expert appointed by the judge or the expert accountant assistant hired by the litigants. This research aimed to identify the judges' perceptions about the role of the expert accountant assistant, especially concerning the expert accountant opinion, as a means to aid and motivated conviction at trial. This is a qualitative and descriptive research, in which we interviewed thirteen judges of the first instance Civil judicial sphere in São Paulo city. The results were evaluated through the application of content Analysis and dialetic-hermeneutic techniques. We identified three categories in the subjects'answers, that benefit, disfavor or contribute to the expert accountant assistant performance. The subjects understand that the role of the expert accountant assistant is relevant to the motivated convincing and aid in the prosecution of a legal conflict, as well as the expert accountant assistant opinion could be used to base the judge's decision-making procedure. Moreover, its absence could harm the judgment and forfeit the judicial capital. Although the expert accountant assistants'role is relevant to the subjects, they pointed out the need to enhance their juridical knowledge, procedural experience, and a more technical and neutral attitude for their job to be better grasped and exploited.
\end{abstract}

Keywords: Expert evidence, Expert accountant assistant, Legal cognition.

\section{INTRODUÇÃO}

Desde o primeiro mandato do então presidente Luiz Inácio Lula da Silva, o acesso ao crédito foi ampliado por intermédio do microcrédito e microfinanças, concessões de recursos colocados à disposição para o consumo ou produção. Esses conceitos são voltados para a população de baixa renda (BARONE; SADER, 2008).

O consumidor desacostumado à realidade de acesso ao crédito e carente de educação financeira, acaba por negligenciar um planejamento, pensando na restituição do crédito a ele concedido. "O crescimento desorientado do crédito produz a inadimplência. A partir daí os empréstimos são interrompidos e a economia reduz a sua atividade" (SAVOIA; SAITO; SANTANA, 2007, p. 1124). 
Um reflexo da inadimplência é o ajuizamento de demandas revisionais e de execução de dívidas, que ocasionam a confrontação de teses jurídicas sobre temas financeiros, levando ao aumento de perícias judiciais e extrajudiciais para opinar acerca da matéria. Esse movimento requer a atuação do perito contador assistente, para assegurar a ampla defesa dos litigantes (NEVES JUNIOR; OLIVEIRA, 2010).

Constata-se a possibilidade de o perito contador assistente atuar no processo cível como agente na elaboração das provas, para facilitar o convencimento motivado do juiz, o julgamento e a resolução do conflito. A cidade de São Paulo possui um Fórum Central, com quarenta e cinco varas cíveis. Cada Vara possui dois juízes, denominados "Titular I" e "Titular II", perfazendo uma população pesquisável de noventa sujeitos de pesquisa. O cenário descrito e o lócus de pesquisa identificado permitem formular a seguinte questão de pesquisa: Qual é a percepção dos juízes cíveis paulistanos de $1^{\circ}$ grau sobre a atuação do perito contador assistente, na produção da prova pericial contábil destinada ao convencimento motivado para o julgamento do conflito legal, à luz do Código de Processo Civil?

O objetivo é identificar e analisar, na percepção de juízes paulistanos de $1^{a}$ instância, o uso do parecer técnico elaborado por peritos assistentes, apresentado na instrução processual, à luz dos artigos 330, $\S 2^{\circ}, 472$ e 917, $\S 3^{\circ}$ do Código de Processo Civil vigente (CPC), como auxílio para a formação do convencimento motivado e julgamento. Justifica-se realizar esta pesquisa, corroborando o argumento de Chalmers e Wright (2011), para os quais a academia deve refletir com maior frequência sobre os problemas do cotidiano.

Pretende-se contribuir para o desenvolvimento da prática profissional dos peritos, em especial dos assistentes, membros da sociedade ligados ao universo das ações judiciais em todo o Brasil. Taveira et al (2013) confirmam haver poucos artigos científicos sobre perícia. Mello (2013, p. 43) afirma que "são escassos os detalhes sobre a forma como deve ser preparado o parecer técnico apresentado junto com a inicial e/ou a contestação do processo judicial".

\section{REFERENCIAL TEÓRICO}

\subsection{A cognição judicial e os poderes instrutórios do juiz}

A cognição é o meio para conceber diferentes possibilidades de procedimentos, vislumbrando a instrumentalidade do processo (WATANABE, 2000). Para o autor, a cognição "é uma importante técnica de adequação do processo à natureza do direito ou à peculiaridade da pretensão a ser tutelada" (WATANABE, 2000, p. 36).

A cognição judicial permite formar uma opinião para o julgamento do mérito, baseada em regras jurídicas públicas, no caso das leis, e regras privadas aplicáveis aos contratos. Ao conjunto de regras aplicadas no Poder Judiciário para a resolução da discussão jurídica se dá o nome de capital jurídico, que reflete o desenvolvimento social de um país (GICO JUNIOR, 2013). Para compreender a produção do capital jurídico é necessário observar o dispêndio de recursos privados dos litigantes, em advogados, peritos, prazos, como 
também investimentos públicos, para a manutenção e formação da jurisprudência, em assessores, técnicos judiciários, pesquisa legal e exposição de fundamentos. Isso ocorre porque os litigantes possuem incentivos para investir no procedimento judicial, pensando no êxito com o provimento do seu pleito. Em outra perspectiva, os juízes tentarão impor suas preferências à sociedade, produzindo decisões que possam ser replicadas por outros juízes (GICO JUNIOR, 2013).

Ao se mirar no comportamento e forma de agir dos litigantes e juízes se cria, indiretamente, uma cultura e procedimentos específicos, como a questão da independência do Poder Judiciário brasileiro em não seguir, exatamente, as leis e regras estabelecidas, nominando-o como ativismo judicial. O ativismo judicial refletido no comportamento dos juízes pode causar insegurança jurídica. Gico Junior (2013, p. 273) atesta que "esse estado judicial não cooperativo em que a cada caso podem ser aplicadas regras jurídicas diferentes, a depender das preferências do magistrado, sem que a jurisprudência caminhe para se tornar uniforme e dominante é o que chamamos anarquismo judicial".

A padronização das decisões que as jurisprudências geram, defendidas por Gico Junior (2013) e Cademartori e Baggenstoss (2011), por um lado, poderiam ceifar o princípio da ampla defesa e contraditório, por outro, visam à celeridade e passam a exigir maior rigor na elaboração das provas oferecidas na instrução processual, elevando tecnicamente os pleitos judiciais.

Cabe ao juiz, a partir de sua cognição, a exata percepção dos poderes instrutórios que possui, em sua dimensão, limites, aplicação e publicidade, sem uma postura autoritária ou passiva, observando o interesse público do Estado, na garantia dos princípios constitucionais. Aos poderes instrutórios, mesmo não expressos em lei, relacionam-se atos que garantam ao juiz autonomia para administrar o trâmite processual, tomar as medidas para a criação de provas e participação das partes.

Neste caminho se destaca o princípio do julgamento antecipado e produção da prova. Sobre produzir ou não provas, deve-se observar o princípio da celeridade. Sob este aspecto, Marinoni (2009) cita a necessidade de haver um tempo mínimo para que os litigantes produzam provas suficientes para que haja a cognição, citando em sua pesquisa "o princípio da duração razoável do processo". Contrapondo e complementando, Gobbo (2013) entende, quanto à celeridade, que apenas se deve pensar na prolatação de sentença, quando a peça inicial já apresentar, desde o seu protocolo, elementos que possam traduzir o pleito almejado pela parte em verdade.

Meneguin e Bugarin (2011, p. 205) acerca da efetividade do processo, em relação à celeridade, entendem que o "processo é o instrumento que viabiliza os demais direitos e, portanto, entende-se que a tutela do Poder Judiciário somente será eficaz se a tramitação do processo for célere".

O tema relativo à celeridade, atrelado à economia processual, também foi abordado por Camelo e Pires (2011). Estes autores comparam o direito contratual americano e o brasileiro, ressaltando a importância de observar o impacto dos contratos no contexto socioeconômico, não somente sob o viés financeiro-econômico. Em maior amplitude, Palombino (2010) salienta o 
princípio da economia judicial, ressaltando que o juiz deve obter o melhor resultado possível na administração de uma controvérsia, de forma mais racional e eficiente.

Ao se pensar em eficiência e efetividade, surge a necessidade de atualizar o princípio do livre convencimento motivado, para o que seria, o convencimento motivado. Neste sentido, o juiz teria que vincular suas razões da formação de convencimento para justificar seu julgamento. Trata-se de uma questão social, para que não haja um sentimento de não funcionamento do Poder Judiciário. A sensação de justiça para uma pessoa comum decorre de o juiz deixar claro a razão da resolução do conflito, indicando as provas ou caminhos que o levaram a tal julgamento, apontando critérios compreensíveis e aceitos (MENDES, 2012).

Evidencia-se a relevância da atuação do perito contador assistente, imbuído de elaborar provas técnicas e científicas, fundamentadas em informações e documentos, de modo a proporcionar o convencimento motivado do juiz, para que este, claramente, vincule-se à prova produzida e julgue o conflito legal. Dessa forma, a atuação do perito contador assistente seria enaltecida, considerando o resultado do seu trabalho como influente para uma decisão judicial, contribuindo para uma sensação de justiça, no sentido mais comum do significado da palavra, por parte das pessoas que buscam o Judiciário.

\subsection{A atuação do perito contador assistente à luz do código de processo civil}

Na prática da perícia contábil na esfera judicial, o perito do juízo é o nomeado pelo juiz, quando este possui uma dúvida que extrapola a matéria do Direito. O perito contador assistente ou assistente técnico é o contratado pelas partes litigantes. Tal contratação pode ocorrer a qualquer momento da discussão judicial ou até antes do início da demanda, pensando-se na assessoria técnica das partes.

O perito nomeado pelo juízo se depara com situações associadas a todas as discussões judiciais que tramitam nos cartórios das varas judiciárias. Uma consequência desta circunstância é a necessidade de o perito nomeado possuir ou obter maior conhecimento e experiência em assuntos distintos, levando-o a uma visão ampla sobre a perícia. De forma diversa, o perito contador assistente ao atuar em questões que se assemelham de um trabalho para outro, atendendo a um segmento específico de advogados, detém um conhecimento mais profundo em uma menor extensão de assuntos.

Ao se empreender no exercício da prática pericial, tomando por base uma ação revisional, considera-se a presença do parecer técnico munido da quantificação do argumento jurídico arguido na inicial, na forma do artigo 330, $\S 2^{\circ}$, do CPC. Da outra parte, ofertado parecer técnico bem formulado, complementando a contestação, esclarecem-se detalhes latentes do pacto, além de desqualificar a quantificação do argumento jurídico pleiteado na inicial, como previsto no artigo 472 do CPC. Esta situação poderá despertar dúvida no juiz, que ao considerar ambos os pleitos fundamentados, ainda que diversos, poderá deferir a prova pericial na fase de instrução, nos moldes do artigo 156 do CPC. 
Dentro do contexto explicitado, o juiz poderá nomear perito de sua confiança e incumbir cada uma das partes à formulação de quesitos e indicação de seu perito assistente, na forma do artigo 465 do CPC. Neste momento, o perito contador assistente, com conhecimento prévio acerca da demanda, deve se unir ao advogado que assessora para apresentar quesitos, buscando delimitar os trabalhos do perito nomeado pelo juízo. Portanto, a formulação de quesitos, além de indicar a metodologia e a opinião técnica do perito contador assistente, complementa a estratégia adotada pelo advogado que assiste (ORNELAS, 2011).

Sá (2007, p. 67) atesta que "os quesitos devem resultar de um esforço conjunto entre o contador e o advogado de modo a possuírem uma forma lógica competente para se chegar às conclusões desejadas como prova". Para que o perito contador assistente efetue um trabalho consistente, inclusive na elaboração dos quesitos é desejável a formulação de demonstrativos e cálculos prévios, para antecipar resultados possíveis da conclusão da perícia, antevendo eventuais riscos ou oportunidades, a serem esclarecidas ao advogado que atende.

Deferida a prova pericial, o perito contador assistente deve manter contato com o perito nomeado pelo juízo, nos termos da Norma Brasileira de Contabilidade, TP 01, itens 6 e 29, contribuir com seu parecer prévio, expondo o seu ponto de vista técnico, além de acompanhar o andamento dos trabalhos periciais, de acordo com o planejamento apresentado no momento da nomeação do perito judicial.

A Norma citada pressupõe a participação do perito contador assistente ao longo dos trabalhos periciais; porém, não é raro que peritos nomeados deixam de considerar essa possibilidade ou minimizem a atuação dos peritos assistentes, contrariando o artigo $466, \S 2^{\circ}$ do CPC. O perito contador assistente, após ter oferecido a sua contribuição técnica, conforme prevê a citada Norma, ao contatar o perito nomeado e perceber que o mesmo possui ponto de vista diverso em algum tema ou quesito, poderá se valer do artigo 469 do CPC, o qual permite a formulação de quesitos suplementares, ainda mais específicos, antes da conclusão e protocolo do laudo pericial. O contato com o perito do juízo é essencial para que o perito contador assistente veja a sua opinião presente no laudo pericial, garantindo a apreciação do juiz, aumentando a obtenção do êxito almejado, satisfazendo a parte que lhe contratou.

Neves Junior e Oliveira (2010) atestam que o perito contador assistente deve deter os mesmos ou até, dependendo da especificidade do assunto, mais conhecimentos que o perito contador nomeado pelo juízo, para que assim se instaure o contraditório, na matéria técnica, de maneira que não prevaleça o ponto de vista do perito nomeado.

Quando o perito nomeado permite a participação dos peritos assistentes, sem prejuízo do planejamento já apresentado, surge a oportunidade de abordar aspectos técnicos de pontos de vistas distintos, elevando o nível da discussão e o progresso da função pericial. Ao se considerar o desenvolvimento do laudo pericial com a presença das opiniões técnicas fundamentadas dos peritos assistentes, contidas nas respostas do perito nomeado aos quesitos 
formulados, a conclusão do laudo pericial pode ser mais consistente e imparcial, pois os pontos controvertidos já terão sido esmiuçados.

Após a conclusão e apresentação do laudo pericial, haverá a oportunidade para a manifestação dos peritos assistentes, por intermédio do parecer técnico, apontando eventuais equívocos, excessos, omissões ou corroborar com o laudo pericial, consoante o artigo 477, $\S 1^{\circ}$, do CPC. Caso haja críticas ou divergências sobre o conteúdo técnico ou conclusão do laudo pericial, o perito nomeado deverá apresentar esclarecimentos, nos termos da do item 41 da Norma PP 01, citada.

Persistindo dúvidas ou pontos controversos, se o juiz considerar que o laudo pericial não é conclusivo ou que merecem guarida as críticas ofertadas pelos peritos assistentes, poderá não se vincular ao laudo pericial, artigo 479 do CPC ou deferir uma nova perícia, na forma do artigo 480 do CPC. A demanda judicial atrelada à interposição de embargos à execução, consoante artigo 917, $\S 3^{\circ}$, também possibilita semelhante atuação dos peritos assistentes, uma vez deferida a prova pericial.

Dos artigos do CPC citados, nota-se a grande possibilidade de o perito contador assistente influenciar, com seu parecer prévio e acompanhamento da perícia, o conteúdo que será levado ao laudo pericial como parte do resultado da perícia, alicerce para o juiz compreender a parte técnica que não conhece e assim poder julgar o conflito.

Peleias et al (2017), afirmam que uma vez o advogado consciente que o resultado da prova pericial pode determinar o rumo do processo, o perito contador assistente passou a atuar como consultor técnico, esclarecendo ao seu contratante dos elementos necessários, inerentes à tomada de decisões e providências nas várias fases de um processo judicial. Ornelas (2011, p. 27) traz argumento que complementa o exposto por Peleias et al (2017), ao afirmar que "o perito-contador, no exercício da função de assistente técnico, desenvolve atividades antes, durante e depois da realização da perícia".

Adicionalmente, além dos artigos já citados, destaca-se a prova técnica simplificada, artigo 464, § $2^{\circ}$, conciliação e mediação, artigos 165 ao 175, audiência, conciliação e mediação na contestação, artigos 334 e 335, além da prova oral e audiência para instrução, artigos 360 ao 368, privilegiam a inserção da atuação do perito contador assistente.

Tais artigos permitem a aproximação do juiz, ensejo para que o perito contador assistente demonstre o seu conhecimento, de modo a causar o convencimento motivado e subsídio para o julgamento da causa, privilegiando a celeridade processual. Também se nota a oportunidade para a atuação do perito contador assistente como assessor do mediador, considerando-se os procedimentos de conciliação e mediação pré-processual, mais exitosos do que o processual, como indicado por Silva (2011).

\subsection{Requisitos necessários ao perito contador assistente}

A contabilidade forense, praticada no exterior, especializada na investigação e solução de conflitos levados à Justiça (PEDNEAULT ET AL, 2012) pode auxiliar a atuação do perito contador assistente no aprimoramento da 
elaboração de seu parecer. Luccas e Relvas (2013) asseveram que a contabilidade forense é uma ferramenta para controle do patrimônio das empresas, que contempla a perícia contábil e o controle interno.

Kushniroff (2012) conceitua a contabilidade forense como uma integração de conhecimentos em contabilidade, auditoria e habilidades investigativas. O autor aponta, na sociedade norte-americana, a atuação do contador forense de forma semelhante ao perito contador, em razão de maiores possiblidades de atuação, enumeradas no Quadro 1.

\begin{tabular}{|c|l|}
\hline \multicolumn{1}{|c|}{ Quadro 1 - Atuação do contador forense no exterior } \\
\hline $\begin{array}{c}\text { Atitude } \\
\text { Deunir-se com o } \\
\text { cliente }\end{array}$ & $\begin{array}{l}\text { Compreencão da atitude } \\
\text { dos pleitos das partes. }\end{array}$ \\
\hline $\begin{array}{c}\text { Verificar os pontos } \\
\text { conflituosos }\end{array}$ & Verificar as possibilidades de como apresentar o pleito. \\
\hline $\begin{array}{c}\text { Realizar uma } \\
\text { investigação inicial }\end{array}$ & $\begin{array}{l}\text { Desenvolver uma investigação preliminar antes de elaborar um } \\
\text { plano de ação. }\end{array}$ \\
\hline $\begin{array}{c}\text { Desenvolver um } \\
\text { plano de ação }\end{array}$ & $\begin{array}{l}\text { Definição dos objetivos a serem alcançados e metodologias a serem } \\
\text { aplicadas. }\end{array}$ \\
\hline $\begin{array}{c}\text { Obtenção de } \\
\text { evidências }\end{array}$ & $\begin{array}{l}\text { Levantar documentos e informações para formar a prova, } \\
\text { relacionado aos objetivos e metodologias escolhidas. }\end{array}$ \\
\hline Análise & $\begin{array}{l}\text { Síntese das transações, cálculo de indenizações, rastreamento de } \\
\text { ativos, cálculos a valor presente, regressão ou análise de } \\
\text { sensibilidade. }\end{array}$ \\
\hline Relatório & $\begin{array}{l}\text { Natureza do trabalho, âmbito da investigação, abordagem } \\
\text { adotada, limitações do escopo e resultados ou opiniões. }\end{array}$ \\
\hline
\end{tabular}

Fonte: Elaborado pelos autores, com base em Kushniroff (2012).

A atuação do contador forense, extraída de Kushniroff (2012), Quadro 1, poderia ser adotada como os tópicos a serem desenvolvidos na atuação e itens de redação do parecer técnico elaborado pelo perito contador assistente, a complementar o afirmado por Mello (2013), quanto à ausência de informações com respeito à confecção do parecer técnico.

Brody, Melendy e Perri (2012) afirmam que mesmo com o tema fraude emergindo na contabilidade forense, nos Estados Unidos, existe carência por boas pesquisas, que deixam de explorar temas ainda não abordados ou cometem equívocos em sua abordagem. O exposto vai ao encontro do exposto por Taveira et al (2013) e Mello (2013).

Efiong (2012) acrescenta, considerando que a Contabilidade é uma ciência social, não se deve apenas observar a inclusão de temas relativos à fraude e contabilidade forense no currículo das faculdades de contabilidade. É preciso analisar a qualidade do ensino, pois cada vez mais se exige competências e habilidades do contador para atuar em questões ligadas à fraude, deixando-se de relevar que o ensino da contabilidade deve refletir as necessidades postas pela sociedade. Nesse sentido Limongi e Miguel (2010) complementam, afirmando quanto à necessidade do melhoramento do ensino superior em Contabilidade no Brasil, referindo-se também ao corpo docente, encarregado de transmitir o conhecimento para aos dissentes. 
Laurin (2013) se atém a necessidade de outros agentes da Justiça, principalmente, Ministério Público e polícia, usuários da contabilidade forense reverem prioridades e critérios para iniciar investigações, coletar e apresentar provas, para melhor escolher as técnicas aplicáveis que influenciarão o trabalho da contabilidade forense. O estudo coloca a ciência forense como meio para abarcar os elementos necessários para formar um "único probatório", capaz contribuir para o sistema judiciário.

Dos estudos citados, extrai-se que o contador forense inicia a sua atuação de forma semelhante à dos peritos contadores no Brasil. Atualmente, as questões ligadas à fraude envolvem diretamente os contadores forenses, a serviço das instituições públicas e privadas. No Brasil são as empresas de auditoria que realizam esses trabalhos. Assim, cabe uma reflexão sobre a formação do perito contador assistente, que poderia melhor abordar e explorar os conhecimentos da auditoria, investigação e marketing, pensando em uma melhor e mais completa atuação no campo da perícia, a estender para outras aplicações correlatas.

Zanna (2011, p. 23) traz o que entende ser os conhecimentos oriundos à prática da perícia, de domínio do perito que "deve possuir (ou adquirir durante o exercício da perícia contábil) conhecimentos relacionados com a Economia, com as finanças, com os tributos, e aqueles conhecimentos pertencentes às relações de trabalho". Neste ínterim Neves Junior et al (2013) indicam como habilidades desejáveis ao perito contador assistente atuarial, o português instrumental, a legislação, a elaboração de relatórios, além da apresentação pessoal.

A divulgação, a aproximação de peritos experientes, a prática de bons preços, estratégias de marketing, além da capacitação técnica são qualidades que o perito contador deve apresentar para que consiga se inserir no mercado de trabalho (NEVES JUNIOR; MELO, 2010).

Ao se pensar em contribuir com a atuação do perito, cabe destacar os conhecimentos inerentes ao exercício da função. Neves Junior et al (2013) indicam como habilidades desejáveis ao perito contador assistente atuarial, o português instrumental, a legislação, a elaboração de relatórios e a apresentação pessoal. Leitão Júnior et al (2012) apontam a importância do conhecimento da linguagem jurídica, para que se estabeleça a adequada comunicação com o juiz. Quanto o parecer técnico do perito contador assistente, Neves Junior et al (2013, p. 49), atestam que deve "possuir boa apresentação, ser bem escrito, mediante utilização de linguagem clara e objetiva", "capaz de demonstrar conhecimento e domínio na matéria examinada, além de convencer as partes envolvidas no processo de que todas as questões foram esclarecidas".

\section{METODOLOGIA}

A escolha do método se dá em função da relação entre os pesquisadores e o objeto da pesquisa, no sentido de como estes enxergam o tema pesquisado e o relacionam dentro de um contexto social, privilegiando o 
apreender com base na experiência de vida do homem (CARDOSO, SANTOS, ALLOUFA, 2015).

Esta pesquisa é descritiva, pois, buscou-se identificar e relatar a percepção de treze juízes paulistanos de $1^{\circ}$ grau, quanto à atuação do perito contador assistente na formação das provas que poderão levá-los ao convencimento motivado e julgamento do conflito, atendo-se a fenômenos, conexões e características acerca do tema pesquisado (CERVO; BERVIAN; SILVA, 2007). É qualitativa, porque as informações obtidas não são passíveis de mensuração. Pedem descrições, compreensões, interpretações, análises de fatos, ocorrências e evidências naturalmente não expressas por dados e números (MARTINS; THEÓPHILO, 2007).

Michelat (1982) atesta que um estudo qualitativo busca estudar sujeitos pela sua representatividade social e não por representação quantitativa. Fontanella, Ricas e Turato (2008), chamam a atenção para o fato de que, com - advento da amostragem por saturação, uma pesquisa qualitativa deve interromper a inclusão de novos participantes na coleta de dados, no ponto em que a inclusão de sujeitos e respostas adicionais não mais acrescentar contribuições ao objeto de estudo.

A pesquisa se valeu de treze entrevistas com juízes, consideradas suficientes pelos autores, obtidas a partir de trinta e seis tentativas, junto a uma população alvo de 90 (noventa) juízes das 45 (quarenta e cinco) Varas Cíveis do Fórum Central da Capital Paulista. Buscou-se extrair junto a esses juízes, tipificados pela Justiça Paulista como "Titular I" e Titular II", informações que ajudassem a identificar como se dá e como deve ser a atuação do perito contador assistente, no auxílio do convencimento motivado e julgamento do conflito legal.

A entrevista é uma técnica de pesquisa para coletar informações, dados e evidências, que busca entender e compreender $O$ significado que entrevistados atribuem a questões e situações (MARTINS, TEÓPHILO, 2007). A entrevista propiciou o acesso aos textos advindos da transcrição das falas dos juízes, descobrindo-se como estes aplicam a lei e enxergam a inserção do perito contador assistente no processo. Silva e Silva (2013) relacionam a possibilidade de acesso ao conceito de corpus, referência eminentemente qualitativa, para a finalidade de expor atributos desconhecidos direcionados a perceber os signos, sentidos e representações presentes na prática social. Foi elaborado um roteiro semiestruturado para as entrevistas, permitindo uma interação flexível. O roteiro possui três construtos e quinze perguntas abertas, relacionados aos objetivos da pesquisa, como exposto no Quadro 2.

Quadro 2 - Entrevistas relacionadas com os objetivos da pesquisa

\begin{tabular}{|l|c|}
\hline \multicolumn{1}{|c|}{ Construtos } & Perguntas \\
\hline $\begin{array}{l}\text { Identificar o perfil e características do trabalho do entrevistado quanto ao } \\
\text { objeto da pesquisa. }\end{array}$ & 1 a 3 \\
\hline $\begin{array}{l}\text { Identificar, na percepção do entrevistado, a presença e o emprego do parecer } \\
\text { técnico elaborado pelo perito contador assistente, apresentado na instrução } \\
\text { processual, consoante os artigos } 330, \S 2^{\circ} \text { e } \S 2^{\circ}, 472 \text { e } 917, \S 3^{\circ} \text {, como auxílio } \\
\text { para a formação do convencimento e julgamento. }\end{array}$ & 4 a 10 \\
\hline
\end{tabular}


Identificar, na percepção do entrevistado, a maior possibilidade e relevância para a atuação do perito contador assistente, observando-se a inclusão da conciliação, mediação e prova simplificada no CPC, como auxílio para a 11 a 15 formação do convencimento e julgamento.

\section{Fonte: Elaborado pelos autores.}

Para examinar o obtido com as entrevistas, aplicou-se a Análise do Conteúdo, um conjunto de técnicas de análise de comunicações, cujo objetivo é ultrapassar as incertezas e enriquecer a leitura dos dados coletados (Mozzato, Grzybovski, 2011). A análise de conteúdo foi desenvolvida em três etapas.

A $1^{a}$ etapa cuidou de transcrever o conteúdo das entrevistas, que foram gravadas, gerando mais de quatro horas de áudio, para tornar possível o manuseio das informações. A $2^{a}$ tratou do agrupamento das respostas obtidas nas conversas com os juízes, relacionando-as aos itens questionados, conforme o roteiro prévio. A $3^{\mathrm{a}}$ visa associar as respostas e as confrontar com os pontos de vista abordados no referencial teórico, buscando-se convergências ou divergências de opiniões.

Buscou-se examinar o significado das palavras contidas no discurso dos entrevistados, para que fosse possível tornar mais clara a escolha dos pesquisadores em indicar para qual caminho se deu a classificação das respostas obtidas. Adotou-se uma aproximação da categorização abordada por Cardoso, Santos e Alloufa (2015), atrelado à Técnica Hermenêutico-Dialética para a análise de conteúdo.

$\mathrm{Na} 1^{a}$ etapa da análise de conteúdo (audição, transcrição e ordenação das entrevistas), percebeu-se que as respostas obtidas, em parte favoreciam (F) a atuação do perito contador assistente, em parte a desfavoreciam (D), privilegiando a ałuação do perito nomeado pelo juízo. Algumas respostas apresentavam contribuições (C) para a atuação do perito contador assistente, no sentido de explicar como cada juiz aplica o CPC. A oitiva da dialética de cada juiz permitiu delinear a $2^{a}$ e $3^{a}$ etapas da análise de conteúdo.

\section{ANÁLISE DOS RESULTADOS}

O conteúdo integral das quinze perguntas e respectivas respostas gerou 58 (cinquenta e oito) páginas transcritas. Assim, pensando-se na efetividade da exposição dos resultados da pesquisa, dos quinze questionamentos do roteiro, são apresentadas as perguntas direcionadas aos juízes e respectivas respostas, consideradas mais relevantes para a conclusão do estudo, apresentadas em Quadros, a seguir. No momento das entrevistas o CPC atual se encontrava em vacância. Por isso, as questões transcritas foram ajustadas a observar os artigos do CPC vigente.

5a: A quantificação nos moldes do artigo $330, \S 2^{\circ}$ do CPC auxilia na comprovação da existência de valor incontroverso em um pacto? Do contrário, o artigo 472 do CPC, possibilita esclarecer o pactuado, de modo a refutar o pleito revisional e dispensar a necessidade da prova pericial? 
Quadro 3 - Valor incontroverso e dispensa do deferimento da prova perícia

\begin{tabular}{|c|c|c|c|c|}
\hline Juiz & Resposta & $\mathbf{F}$ & D & C \\
\hline $1^{a}$ & Não muito. Normalmente não. [...]. & & $x$ & \\
\hline $2^{a}$ & $\begin{array}{l}\text { Permite, mas do ponto de vista do autor, não quer dizer que eu entenda } \\
\text { aquilo como correto, mas é um ponto de partida pra discussão. } \\
\text { Dificilmente isso acontece, a não ser que sejam valores quase } \\
\text { convergentes das duas partes, [...], mas se são valores muito } \\
\text { discrepantes, dai é necessário o perito. [...]. }\end{array}$ & & $X$ & $X$ \\
\hline $3^{a}$ & $\begin{array}{l}\text { [...] Como na prática isso realmente não acontece, o juiz é obrigado a } \\
\text { nomear o perito, ai sim vem a figura do assistente técnico e tal, mas } \\
\text { também é raro, não é uma figura comum, porque muitas vezes estão } \\
\text { brigando pra ver quem vai pagar o perito, pois ninguém gostaria de ter } \\
\text { que pagar o ônus pra depois reaver na sucumbência. Então ninguém } \\
\text { quer pagar na verdade a perícia inicial, essa é a grande discussão e na } \\
\text { verdade também, muitas vezes não estão dispostos a ter arrolados os } \\
\text { assistentes técnicos e isso acaba dificultando como um todo o } \\
\text { julgamento. [...]. }\end{array}$ & & $X$ & $X$ \\
\hline $4^{a}$ & $\begin{array}{l}\text { Sim. Não impede, pois vai depender do conteúdo dessa prova pericial } \\
\text { e do conteúdo da natureza da controvérsia citada pelo réu, } \\
\text { dependendo do alcance não tem nenhum problema. O que acontece } \\
\text { às vezes é que essa parte vai ficar controvertida e você precisa dar } \\
\text { direito ao contraditório e decidir sobre isso. É um juízo de valor. [...]. }\end{array}$ & & $X$ & \\
\hline $5^{a}$ & $\begin{array}{l}\text { [...] É raro de acontecer, mas se algum momento os pareceres } \\
\text { coincidirem pode ser dispensada a prova pericial. É uma regra } \\
\text { processual de utilidade, mas não é algo que acontece na prática, } \\
\text { porque tecnicamente o consumidor tem a pretensão de cláusulas pra } \\
\text { excluir, [...]. Então, com essas práticas, para se julgar o processo se } \\
\text { acaba designando a perícia. [...]. }\end{array}$ & & $X$ & $X$ \\
\hline $6^{a}$ & $\begin{array}{l}\text { Sim. Eu acredito que só se for uma questão assim bem de simples } \\
\text { solução, se do contrário o juiz pode continuar se valendo do perito. } \\
\text { Não, depende do caso e do tipo de prova. }\end{array}$ & & $X$ & \\
\hline $7^{a}$ & $\begin{array}{l}\text { Dá indícios de que há um valor controvertido. Se forem diversos, } \\
\text { considerando que o juiz não tem conhecimento técnico específico em } \\
\text { área contábil-financeira, via de regra, ele vai nomear o perito para } \\
\text { dirimir as dúvidas [...]. Entendo que no caso de laudo oferecido pelas } \\
\text { partes, o autor deve instruir a inicial, o réu instruir a contestação, } \\
\text { tratando-se de prova técnica, demora que o juiz no momento do } \\
\text { julgamento antecipado da lide possa averiguar se é necessário sanear } \\
\text { o processo e marcar uma perícia. }\end{array}$ & & $X$ & \\
\hline $8^{a}$ & $\begin{array}{l}\text { Como eu disse, o valor incontroverso precisa estar bem claro quanto à } \\
\text { incorreção do valor total, no caso, se tiver alguma coisa que não está } \\
\text { muito clara fica difícil a aplicação, [...]. Não, nunca. Eu me lembro } \\
\text { desse artigo, mas eu nunca utilizei. Nunca apliquei. [...]. Depende da } \\
\text { complexidade. }\end{array}$ & & $X$ & \\
\hline $9^{a}$ & $\begin{array}{l}\text { Na verdade a ideia é que desde o início se aponte, ainda que não se } \\
\text { saiba, com certeza, quem tem a razão, mas que se aponte o valor } \\
\text { incontroverso para você delimitar a discussão. [...]. Agora, como o juiz } \\
\text { precisa decidir, ele não pode se furtar de decidir, ele é o destinatário da } \\
\text { prova, se ele entende na realidade que há convencimento suficiente } \\
\text { independentemente da prova pericial, perfeitamente possível que ele } \\
\text { julgue sem a prova, a despeito de ser desafiada por recurso, ser } \\
\text { passível de recurso a decisão dele, mas eu não vejo que fira o } \\
\text { contraditório. [...]. }\end{array}$ & & $X$ & $X$ \\
\hline
\end{tabular}




\begin{tabular}{|c|c|c|c|}
\hline $10^{a}$ & $\begin{array}{l}\text { Eu nem uso, [...]. O juiz, dependendo do que está no processo, ele pode } \\
\text { dispensar qualquer outra prova se ele achar que com o que está nos } \\
\text { autos, ele pode formar a convicção dele. Seria até possível se, com o } \\
\text { que está nos autos, ele consegue julgar e não há a necessidade de } \\
\text { nenhuma análise de um especialista da área, seria possível. Não, pelo } \\
\text { que me lembre, nunca aconteceu. [...] }\end{array}$ & & $x$ \\
\hline $11^{a}$ & $\begin{array}{l}\text { Difícil, também, te dar uma resposta com exatidão com relação a isso. } \\
\text { [...]. Em regra, pode-se dizer que ele auxilia na comprovação. [...]. } \\
\text { Porque se for conta meramente aritmética, que não dependa de um } \\
\text { auxilio um pouco mais aprofundado de um perito do juízo, pode ser que } \\
\text { sim. Mas em regra, a divergência é tamanha, a complexidade técnica } \\
\text { envolvida naquela divergência, que você demanda a nomeação de } \\
\text { um perito para tal esclarecimento para subsidiar o juiz na prolação da } \\
\text { decisão. Aí vai variar da complexidade da prova a ser feita, [...]. }\end{array}$ & & $x$ \\
\hline $12^{a}$ & $\begin{array}{l}\text { Auxiliaria, auxiliaria na comprovação da existência de um valor } \\
\text { incontroverso. Poderia sim, poderia. Mas é o que eu falo, nos casos, em } \\
\text { geral, o que se observa é mais uma questão de discussão jurídica } \\
\text { mesmo, de aplicação de determinado fundamento jurídico, no caso, } \\
\text { interpretação do contrato, do que de cálculo, mas sim, auxiliaria e } \\
\text { também dispensaria a prova pericial se fosse o caso. [...]. }\end{array}$ & $X$ & \\
\hline $13^{a}$ & $\begin{array}{l}\text { Sim, esse é um aspecto prático muito importante, porque evidencia um } \\
\text { valor incontroverso que muitas vezes atenua o sofrimento da parte } \\
\text { inocente no processo. [...] } \bigcirc \text { que acontece, eventualmente esse } \\
\text { parecer técnico pode aumentar o ônus da parte contrária de se } \\
\text { contrapor a aquela alegação, [...]. Então, trazer o parecer técnico, é no } \\
\text { mínimo útil, e muitas vezes pode trazer muita vantagem à parte no } \\
\text { gerenciamento do processo porque faz com que o ônus da produção } \\
\text { da prova pericial se transfira para a outra parte. }\end{array}$ & $X$ & \\
\hline
\end{tabular}

Fonte: Elaborado pelos autores.

A pergunta foi feita ao se pensar em qual medida o parecer técnico apresentado pelo perito contador assistente, na fase de instrução processual, auxilia na formação da cognição do juiz, em questões revisionais, artigo 330, § 2, a ponto de gerar ou não convencimento para o julgamento, de modo a prescindir da nomeação do perito do juízo.

Há menção de que o uso do artigo $330, \S 2^{\circ}$ do CPC, objeto do parecer técnico do perito contador assistente, auxilia na indicação do valor incontroverso, na opinião de oito juízes. Quanto à possibilidade de dispensa do deferimento da prova pericial, na forma do artigo 472 do CPC, onze juízes afirmam que isso pouco ocorre, apenas nos casos em que as partes litigantes apresentem, por intermédio dos peritos assistentes que as assessoram, valores de apurações aproximados. Dois juízes admitiram a possibilidade de dispensar a prova pericial e adotar os pareceres dos peritos assistentes, mesmo não sendo uma prática corriqueira.

Como contribuição, salienta-se a resposta $3^{a}$ entrevistado ao afirmar que, mesmo com a nomeação do perito do juízo é incomum a presença dos peritos assistentes, pois as partes não se dispõem a pagar os seus honorários, o que acaba prejudicando o julgamento. Tal ponto de vista é relevante ao se pensar que a falta do investimento em peritos pode comprometer aprimoramento do capital jurídico gerador da segurança jurídica, como abordado por Gico Junior (2013), Cademartori e Baggenstoss (2011). 
O $13^{\circ}$ entrevistado, como contribuição, cita que a apresentação do parecer técnico do perito contador assistente pode conferir vantagem, no sentido de fazer com que a outra parte que integra a discussão aprimore a sua defesa técnica. O exposto vai ao encontro dos pensamentos de Peleias et al. (2017) e Ornelas (2011), quanto à relevância da atuação do perito contador assistente como consultor, assistindo o seu cliente e o respectivo advogado, antes, durante e depois da discussão judicial.

9a: Considerando o auxílio do parecer do perito contador assistente no julgamento, a sentença deve fazer menção ao parecer em razão do princípio do convencimento motivado? Deve haver o vínculo do juiz à prova produzida e acostada aos autos na fase de instrução processual?

Quadro 4 - Convencimento motivado e vinculação a prova

\begin{tabular}{|c|c|c|c|c|}
\hline Juiz & Resposta & $\mathbf{F}$ & D & $C$ \\
\hline $1^{\mathrm{a}}$ & $\begin{array}{l}\text { Algumas vezes se faz, quando usado como fundamento, se não, não. Sim, } \\
\text { o juiz sempre decide com o fundamento na prova que está nos autos. }\end{array}$ & $x$ & & \\
\hline $2^{a}$ & $\begin{array}{l}\text { Não. Não necessariamente. Já houve casos em que eu vi o laudo pericial } \\
\text { e entendi que destoou do objeto da ação e mandei fazer outra. Óbvio } \\
\text { que na maior parte das vezes, sendo o perito da nossa confiança a gente } \\
\text { acaba acolhendo o laudo dele, mas é bom sempre dar uma olhada, } \\
\text { porque às vezes acontece de destoar. Se eu entendi que foi correto } \\
\text { aquele laudo, que ele partiu das premissas corretas eu acolho e inclusive } \\
\text { transcrevo alguns trechos desse laudo na sentença. }\end{array}$ & $x$ & & \\
\hline $3^{a}$ & $\begin{array}{l}\text { Sim, sem dúvida é obrigatório fazer isso. Na verdade você tem } \\
\text { obrigação, na medida em que aquilo é elemento de prova, a convicção } \\
\text { é um parecer técnico, às vezes até contra o do perito oficial, às vezes } \\
\text { acontece, não muito, cálculo não é tão comum, mas em perícia médica, } \\
\text { às vezes você vê lá uma coisa contrária e com mais fundamento até que } \\
\text { a perícia judicial, então você na verdade fica com o parecer do } \\
\text { assistente. }\end{array}$ & $x$ & & \\
\hline $4^{a}$ & $\begin{array}{l}\text { A questão do perito e do assistente ele deve fazer menção ao } \\
\text { convencimento motivado sim, desde que, ela faça impugnaços do } \\
\text { conteúdo da prova, de repente não traz nenhum, não é motivo pra fazer, } \\
\text { mas sempre no sentido do conteúdo, o que são juros, qual o conteúdo } \\
\text { dos juros e não em todas as hipóteses. Quanto ao vínculo, nunca. }\end{array}$ & $x$ & $x$ & \\
\hline $5^{a}$ & $\begin{array}{l}\text { Sim, do ponto de vista de que, primeiro, o juiz pode adotar os argumentos } \\
\text { às vezes do próprio assistente, ou adotando o argumento da perícia } \\
\text { oficial e ser contra o parecer do assistente, ele vai se valer de um } \\
\text { argumento dele pra falar por que não cabe o argumento do assistente, } \\
\text { mas normalmente o esclarecimento do perito já traz essa crítica ao } \\
\text { assistente da forma técnica. Sim. }\end{array}$ & $x$ & & \\
\hline $6^{a}$ & Eu acho que não necessariamente. Sim, com certeza eu acho que sim. & & $X$ & $\lambda$ \\
\hline $7^{a}$ & $\begin{array}{l}\text { Sim, o juiz deve mencionar que analisando o laudo foi apurado esse } \\
\text { valor, todavia, conforme o perito contador assistente apurou laudo } \\
\text { divergente é indispensável. Sim, o juiz sempre vai, na minha opinião, [...], } \\
\text { mas sempre que eu me refiro a uma prova eu falo, o autor juntou } \\
\text { documento, o réu, as partes divergiram, o perito esclareceu o ponto X o } \\
\text { ponto Y, sempre haverá menção a quem produziu a prova. }\end{array}$ & $x$ & & \\
\hline $8^{a}$ & $\begin{array}{l}\text { Não adotaria um parecer de um assistente. Eu prefiro nomear um perito, } \\
\text { não tenho segurança. Sim, absolutamente sim. }\end{array}$ & & $x$ & \\
\hline
\end{tabular}




\begin{tabular}{|c|c|c|c|}
\hline $9^{a}$ & $\begin{array}{l}\text { Sim. Na verdade, o juiz não está vinculado ao resultado da prova } \\
\text { técnica. Não está vinculado, ele pode julgar contra, porque é o livre } \\
\text { convencimento, ele pode julgar contra a conclusão técnica, mas } \\
\text { evidente que ele precisa fundamentar o porquê está julgando contra a } \\
\text { prova técnica. Então, uma coisa é a fundamentação, outra coisa é ele } \\
\text { estar vinculado à prova técnica, não está vinculado. }\end{array}$ & $x$ & $x$ \\
\hline $10^{a}$ & $\begin{array}{l}\text { Nós temos que fundamentar qualquer direção que for tomada nos } \\
\text { julgados. Eu tenho que fundamentar a decisão. Se eu resolver afastar o } \\
\text { que o perito concluiu, eu terei que fundamentar e dizer o porquê. Sempre } \\
\text { tem essa liberdade, mas tem que ser fundamentada. }\end{array}$ & $X$ & \\
\hline $11^{\mathrm{a}}$ & Sim. Sim, claro. Sim, sim. & $X$ & \\
\hline $12^{a}$ & $\begin{array}{l}\text { Sim. Não necessariamente, mas se for para refutar aquela prova pericial } \\
\text { realizada, tem que também motivar, então assim, ao menos menção e se } \\
\text { for o caso designar outro perito para fazer uma nova perícia, se for o caso } \\
\text { de análise técnica. Agora se for para acolher aquilo que foi analisado } \\
\text { pelo laudo, o que foi observado, a conclusão do laudo eu acredito que } \\
\text { tenha que fazer menção sim. }\end{array}$ & $X$ & \\
\hline $13^{a}$ & $\begin{array}{l}\text { Sim, não há problema nenhum e, a rigor, se o que está fundando a } \\
\text { convicção do juiz é o parecer, é absolutamente regular que o parecer } \\
\text { seja mencionado na decisão. Uma das regras basilares da decisão } \\
\text { judicial é que ela tem que estar fundada no que consta no processo. } \\
\text { Então, num certo sentido, o juiz sempre está vinculado à prova que foi } \\
\text { produzida. Ele não pode fundamentar a decisão deles algo que não está } \\
\text { no processo, [...]. }\end{array}$ & $x$ & \\
\hline
\end{tabular}

Fonte: Elaborado pelos autores.

Considerando a presença do parecer técnico do perito contador assistente, na forma citada na pergunta 5, anterior, perguntou-se aos juízes se estes fazem uso de tal conteúdo e ao fazê-lo, se possuem o hábito de citar o parecer como esteio de sua fundamentação para o julgamento do conflito.

Dez entrevistados entendem que havendo parecer dos peritos assistentes ou até mesmo o laudo do perito do juízo, sendo adotado como fundamento para o convencimento motivado e julgamento do conflito deverá ocorrer menção na sentença do emprego da prova. Tal percepção é favorável à atuação do perito contador assistente. Nesta perspectiva, nota-se que o parecer técnico elaborado pelo perito contador assistente pode ser utilizado como meio para a cognição judicial, abordada por Watanabe (2000), bem como, para o aprimoramento do capital jurídico, como auxílio na formação de entendimentos mais técnicos, como defendido por Gico Junior (2013).

Dois entrevistados afirmam que não necessariamente 0 juiz deve mencionar o parecer ou laudo pericial na fundamentação do julgamento. $\bigcirc 9^{\circ}$ entrevistado justifica seu ponto de vista invocando o livre convencimento motivado, ao invés do convencimento motivado, que vai contra o entendimento de Mendes (2012), que defende a clareza no convencimento motivado como meio para aproximar o Judiciário do senso comum do que venha a ser Justiça.

Cita-se a opinião do $8^{\circ}$ entrevistado, como desfavorável à apuração do perito contador assistente, dizendo que não adotaria o parecer técnico, por falta de segurança. Pensando em reverter este quadro, ressalta-se a importância dos peritos assistentes apresentarem um trabalho cada vez mais bem elaborado e aprimorado, como expõe Neves Junior et al (2013). 
10a: O parecer apresentado pelo perito contador assistente apenas deve versar sobre questões contábil-financeiras ou o conhecimento jurídico também pode auxiliar o perito contador assistente na redação e melhor explicação do conteúdo técnico como meio para auxiliar as decisões do magistrado?

Quadro 5 - O conhecimento jurídico do perito contador assistente

\begin{tabular}{|c|c|c|c|c|}
\hline Juiz & Resposta & $\mathbf{F}$ & D & C \\
\hline $1^{a}$ & Não, só questão contábil. & & $x$ & \\
\hline $2^{a}$ & $\begin{array}{l}\text { [...] se puder traduzir em termos jurídicos pra gente seria muito mais fácil } \\
\text { pra eu adotar na sentença, porque muitas vezes vem um laudo que só } \\
\text { indica anexo } 1 \text {, anexo } 2 \text {, e você não sabe como é que foi a conclusão, } \\
\text { não sabe como aplicar no caso. [...]. }\end{array}$ & $x$ & & $\mathrm{x}$ \\
\hline $3^{a}$ & $\begin{array}{l}\text { Sem dúvida, quanto mais próximo ele tiver da técnica judicial, melhor pra } \\
\text { ele porque ele sabe que não pode enfrentar diretamente o mérito ou } \\
\text { tentar decidir pelo juiz, mas ele pode tangenciar isso colocando } \\
\text { argumentos jurídicos junto com a técnica, que vem ajudar a respaldar o } \\
\text { seu parecer, melhor ainda. }\end{array}$ & $x$ & & \\
\hline $4^{a}$ & $\begin{array}{l}\text { Olha, eu acredito que o parecer técnico do assistente, quanto o do } \\
\text { perito judicial precisa conhecer questões jurídicas, até para não avançar } \\
\text { onde não deve é nesse sentido, pois se ele começar a envolver questões } \\
\text { jurídicas, e às vezes isso faz bem para as partes, você às vezes acaba } \\
\text { discutindo mais um parecer do que a própria decisão. [...]. }\end{array}$ & $x$ & & \\
\hline $5^{a}$ & $\begin{array}{l}\text { Nem o perito e nem o assistente podem exprimir qualquer opinião } \\
\text { jurídica, porque isso é atribuição do juiz, ele só é chamado na área de } \\
\text { expertise dele. }\end{array}$ & & $x$ & \\
\hline $6^{a}$ & Acho que apenas pode versar sobre questões contábil-financeiras. & & $x$ & \\
\hline $7^{\mathrm{a}}$ & $\begin{array}{l}\text { Bom, com base nas determinações, nas previsões do Código de Processo } \\
\text { Civil, em relação ao perito, o perito também não deve se esmiuçar nas } \\
\text { questões jurídicas, por ele não ser expert na área jurídica, ele é expert } \\
\text { em engenharia, medicina, contabilidade, mesmo o assistente não deve } \\
\text { entrar na seara que não é da sua competência. }\end{array}$ & & $x$ & \\
\hline $8^{a}$ & $\begin{array}{l}\text { Vejo com um pouco de receio essa interferência dele em questão } \\
\text { jurídica, salvo, só se for aquilo que já se encontra conhecido na técnica } \\
\text { jurídica e for de fácil apreensão por ele. Prefiro que se restrinja às }\end{array}$ & & $x$ & \\
\hline $9^{a}$ & $\begin{array}{l}\text { Em princípio a prova técnica, tanto aquela produzida pelo perito judicial } \\
\text { como a produzida pelos assistentes, ele deve se ater às questões técnicas } \\
\text { e não às questões jurídicas. }\end{array}$ & & $x$ & \\
\hline $10^{a}$ & $\begin{array}{l}\text { [...]. Geralmente eles se atêm só as questões técnicas, pois eles não têm } \\
\text { o conhecimento jurídico. A maioria deles não tem conhecimento jurídico, } \\
\text { praticamente todos não têm conhecimento jurídico para fazer uma } \\
\text { menção a essas questões. Mas, dependendo da situação, até se ele tiver, } \\
\text { e usar termos jurídicos, alguma coisa assim, eu não vejo problema. Ele só } \\
\text { não vai poder dizer o que ele entende, se colocando no papel de juiz. } \\
\text { Isso ele não pode fazer, ser o julgador. Mas se ele souber usar as } \\
\text { expressões, dá o caminho, já que ele conhece o meio, o ordenamento, } \\
\text { na elaboração do laudo, não vejo problema. }\end{array}$ & $x$ & & $x$ \\
\hline $11^{\mathrm{a}}$ & De preferência se ele tiver formação jurídica, é melhor. A resposta é sim. & $\mathrm{X}$ & & \\
\hline
\end{tabular}




\begin{tabular}{|c|l|l|l|l|}
\hline $12^{a}$ & $\begin{array}{l}\text { Sim, o parecer técnico em que o perito tenha conhecimento jurídico, } \\
\text { ainda mínimo que seja, auxilia muito mais do que um que só meramente } \\
\text { técnico, mas de qualquer forma, aquela prova foi chamada ao processo } \\
\text { pela necessidade da análise técnica. Obviamente a questão jurídica é o } \\
\text { juiz que vai decidir. Se um perito tem um conhecimento jurídico, se ele } \\
\text { tem conhecimento de termos jurídicos isso auxilia, do que uma prova } \\
\text { totalmente bem técnica, é mais difícil de ler um laudo, do que um laudo } \\
\text { que é mais adequado ao processo, ao processo judicial. }\end{array}$ & & & \\
\hline & $\begin{array}{l}\text { O perito deve, da própria conveniência dele, ele deve se abster de fazer } \\
\text { considerações jurídicas no trabalho dele. O conhecimento jurídico pode } \\
\text { ajudá-lo a entender melhor o processo, a entender melhor as questões } \\
\text { relevantes, que são controvertidas no processo e pode, portanto, auxilia- } \\
\text { lo a realizar o trabalho dele. [...]. Nada de que o perito falar em termo de } \\
\text { conhecimento jurídico pode ser aproveitado no processo. Então não } \\
\text { adianta o perito se desgastar e se arriscar a fazer considerações sobre } \\
\text { essa matéria. [...]. }\end{array}$ & $x$ & $x$ \\
\hline
\end{tabular}

Fonte: Elaborado pelos autores.

A pergunta direcionada aos entrevistados se propôs a saber se, entre os conhecimentos desejáveis ao perito contador assistente e os requisitos que deve contemplar o seu parecer, até onde é oportuno fazer menção à legislações ou adotar termos jurídicos.

Sete entrevistados entendem não haver problema e até consideram positivo o parecer do perito contador assistente empregar termos jurídicos para a melhor compreensão pelo juiz do conteúdo técnico. A análise traz a importância da linguagem jurídica para a compreensão do conteúdo técnico pelo juiz. Deste modo, além dos conhecimentos desejáveis ao perito contador assistente, abordados em Zanna (2011), Neves Junior et al (2013) e Neves Junior e Melo (2010), não se pode deixar de considerar os conhecimentos na área do Direito.

Em complemento, O Quadro 5 revela um achado da pesquisa, pois, confirma e complementa o observado por Leitão Júnior et al (2012) e ainda, aponta para a importância de conhecer o CPC, para a tradução dos termos técnicos contábeis à linguagem jurídica, melhor delineando os pontos controvertidos a serem esclarecidos e até para não avançar na competência do juiz.

11 ${ }^{\text {a: }}$ Como o parecer técnico poderia ser aprimorado para melhor auxiliar o convencimento do juiz na fase de instrução processual? O parecer técnico atualmente pode ser considerado como item que contribui para o convencimento e julgamento do conflito legal? Excelência já adotou parecer de perito contador assistente como base para 0 convencimento $e$ julgamento?

Quadro 6 - O parecer técnico como convencimento motivado

\begin{tabular}{|c|l|c|c|c|}
\hline Juiz & \multicolumn{1}{|c|}{ Resposta } & D & C \\
\hline $1^{a}$ & $\begin{array}{l}\text { Precisa explicar para quem não tem conhecimento técnico contábil. } \\
\begin{array}{l}\text { Ser claro, ter clareza. O parecer de alguma das partes normalmente } \\
\text { não tanto, mais o do perito judicial. }\end{array}\end{array}$ & X \\
\hline $2^{a}$ & $\begin{array}{l}\text { O que eu queria mesmo de um laudo, que nem sempre acontece é } \\
\text { que tivesse uma conclusão clara, por exemplo, a dúvida é se houve } \\
\text { excesso no débito ou não, que indique muito claro "houve excesso" ou }\end{array}$ & $X$ & $X$ \\
\hline
\end{tabular}

138 Revista Contabilidade Vista \& Revista, ISSN 0103-734X, Universidade Federal de Minas Gerais, Belo Horizonte, v. 29, n. 2, p. 122-149, mai./ago. 2018 


\begin{tabular}{|c|c|c|c|c|}
\hline & $\begin{array}{l}\text { então "há cumulação de comissão de permanência e juros de mora", } \\
\text { nem sempre vem assim e fica muito esparso, a conclusão não vem } \\
\text { resumida, então você fica às vezes sem resposta, precisa ser mais } \\
\text { conciso e mais conclusivo. [...]. }\end{array}$ & & & \\
\hline $3^{a}$ & $\begin{array}{l}\text { Cursos, uma formação mais adequada, também é outra coisa, parece } \\
\text { que o sujeito não vai muito bem na profissão dele e ai quer vir para o } \\
\text { Judiciário pra ajudar a fazer perícia. Então, às vezes é um profissional } \\
\text { que não deu muito certo na prática e migra pra cá sem muita técnica. } \\
\text { E na verdade isso aqui é extremamente técnico e a pessoa deveria } \\
\text { aprimorar a forma, inclusive de petição, de colocação das frases, } \\
\text { talvez até um melhor engajamento até linguístico, parece que falta um } \\
\text { pouco isso, [...]. O ponto que a gente percebe bastante forte diz } \\
\text { respeito à conclusão do laudo. Então, a conclusão vem com três } \\
\text { laudas, precisa ter nexo e causalidade, conclusão é nexo causal. Em } \\
\text { matérias médicas sim. Em matéria contábil, pra ser bem honesto eu não } \\
\text { me lembro. Na parte contábil, parece, o sujeito já tem uma } \\
\text { parcialidade, que dificilmente ele vai recusar o serviço, o autor não vai } \\
\text { juntar se ele fizer um parecer contrário. [...]. }\end{array}$ & & $x$ & $\mathrm{X}$ \\
\hline $4^{a}$ & $\begin{array}{l}\text { [...] E muitas vezes quando vem um laudo pericial ele faz um trabalho } \\
\text { como se o contrato fosse, na verdade não como o contrato é, a partir } \\
\text { do que o contrato é ai ele faz as teses deles, isso que está errado então } \\
\text { essa é a conta, seria a comparação. [...]. São comparações, muitas } \\
\text { vezes o assistente técnico traz como se a tese dele fosse a vencedora, } \\
\text { como se fosse acolhida e não é, se a questão é quantum eu não posso } \\
\text { permitir isso, eu preciso é comparar. [...]. }\end{array}$ & & $x$ & $\mathrm{X}$ \\
\hline $5^{a}$ & Sendo claro e objetivo naquilo que ele se propõe. Pra mim sim. Já. & $x$ & & \\
\hline $6^{a}$ & $\begin{array}{l}\text { Eu acho que ele precisa tentar ao máximo comentar o resultado da } \\
\text { prova pericial mesmo, não entrando em questões de mérito e jurídicas } \\
\text { da demanda. Acho que não. Não, nunca. }\end{array}$ & & $x$ & $\mathrm{X}$ \\
\hline $7^{a}$ & $\begin{array}{l}\text { Para auxiliar ele deveria ser sempre, primeiro, sucinto, pois muitas vezes } \\
\text { é muito extenso e não auxilia o julgamento, o juiz já tem que ler muito, } \\
\text { o senhor está vendo aqui, a quantidade de processos por dia, [...], um } \\
\text { bom laudo é aquele que é claro, simples, com linguagem técnica, mas } \\
\text { não de rigor extremo, de modo que um leigo possa entender e tratando } \\
\text { do assistente que ele possa cotejar aquilo que o perito falou de uma } \\
\text { maneira clara, se tem um cálculo do perito ele demonstrar, através de } \\
\text { um cálculo semelhante, onde houve a divergência na aplicação de } \\
\text { determinado índice, de determinado valor que foi apurado. Sim, o } \\
\text { contraditório é sempre profícuo. Sim, já adotei. }\end{array}$ & $\mathrm{x}$ & & $\mathrm{X}$ \\
\hline $8^{a}$ & $\begin{array}{l}\text { Como eu disse a gente considera o estudo técnico, mas não toma ele } \\
\text { como um motivo decidido, como é da parte eu prefiro não levar tanto } \\
\text { em consideração. Se for um parecer técnico muito bem } \\
\text { fundamentado... Pra ser franco, eu já vi laudo, ou melhor, já fiquei } \\
\text { sabendo de pessoas, amigos, que o estudo técnico desconstituiu a } \\
\text { perícia, mas eu nunca, na minha carreira, aconteceu isso, mas um } \\
\text { estudo técnico é um estudo técnico, em um conflito ele pode } \\
\text { prevalecer, mas não é o que eu vejo. }\end{array}$ & & $x$ & \\
\hline $9^{a}$ & $\begin{array}{l}\text { Na realidade, para o juiz, o importante é que o assistente, ele } \\
\text { efetivamente acompanhe a produção da prova, ele acompanhe, } \\
\text { passo a passo, o trabalho do perito judicial. Até pra, de certa forma, } \\
\text { fiscalizar fora do processo o trabalho do perito judicial e, ai sim, } \\
\text { discordando tecnicamente apresentar um laudo divergente, ai sim, ele } \\
\text { vai auxiliar o juiz. Sim. Claro. }\end{array}$ & $\mathrm{x}$ & & $\mathrm{X}$ \\
\hline
\end{tabular}




\begin{tabular}{|c|c|c|c|}
\hline $10^{a}$ & $\begin{array}{l}\text { Eles têm que se ater ao que é perguntado pelas partes, aos quesitos, e } \\
\text { eventualmente atacar o que o perito respondeu. É isso, eles não têm } \\
\text { que mudar. É isso o que eles devem fazer. Sim, claro. Já, eu já afastei } \\
\text { conclusão de perito e segui o que o assistente trouxe para o processo. } \\
\text { Já fiz isso sim. }\end{array}$ & $X$ & \\
\hline $11^{a}$ & $\begin{array}{l}\text { [...]. Geralmente os juízes acabam nomeando um perito técnico que } \\
\text { tem um sistema de trabalho que se coaduna com a compreensão dele } \\
\text { a respeito daquela prova técnica, seja um perito contábil ou um } \\
\text { médico. Vai da redação, da capacidade de clareza, do didatismo do } \\
\text { perito, do didatismo da compatibilidade do juiz com aquele método } \\
\text { que ele usa ou não. Sim, pode ser sim. Aí eu não posso te responder por } \\
\text { que eu simplesmente não me lembro de todos os casos que eu julgo, } \\
\text { mais pelo princípio do livre convencimento do juiz, nada impede que } \\
\text { ele julgue adotando o parecer técnico do assistente de uma das } \\
\text { partes. }\end{array}$ & $x$ & \\
\hline $12^{a}$ & $\begin{array}{l}\text { Que a experiência do perito em trabalhar com processos judiciais faz } \\
\text { com que ele saiba esclarecer exatamente os pontos que são } \\
\text { necessários para o deslinde e solução da causa. Sim. Muito difícil. } \\
\text { Nunca afastei a perícia feita pelo perito nomeado, pelo perito do juízo. } \\
\text { Pelo que me recordo é muito raro isso acontecer. }\end{array}$ & & $x$ \\
\hline $13^{a}$ & $\begin{array}{l}\text { [...]. Tecnicamente é perfeitamente possível que o juiz, depois de } \\
\text { produzida a prova pelo perito judicial, produzidos os pareceres dos } \\
\text { assistentes técnicos, é dada a oportunidade do perito se manifestar } \\
\text { sobre essas impugnações, é dada as partes, subsidiadas pelos peritos, } \\
\text { pelos assistentes, se manifestarem sobre os esclarecimentos do perito; o } \\
\text { juiz é livre para adotar qualquer elemento de convicção que tenha no } \\
\text { processo, inclusive a visão alternativa do assistente técnico. Isso não é } \\
\text { problemático, do ponto de vista jurídico. }\end{array}$ & $X$ & \\
\hline
\end{tabular}

Fonte: Elaborado pelos autores.

Esta pergunta almejou descobrir, na opinião dos juízes, como o parecer elaborado pelo perito contador assistente pode ser melhorado, quanto aos conhecimentos aplicados, forma de escrita, entre outros. Também se procurou identificar se os magistrados adotam o conteúdo do parecer técnico confeccionado pelo perito contador assistente, para fundamentar o seu julgamento.

Sete entrevistados entendem importante e inclusive já adotaram o parecer do perito contador assistente como convencimento para auxiliar no julgamento de um conflito legal, percepção favorável à atuação do perito contador assistente. Porém, não se pode deixar de considerar que seis juízes afirmam não ser comum adotar o parecer dos peritos assistentes, no que se pode notar, principalmente, em razão da parcialidade do conteúdo trazido no parecer, como citado pelos entrevistados 4 e 6 .

No Quadro 1, elaborado a partir do estudo de Kushniroff (2012), seria possível pensar no aprimoramento das etapas do trabalho inerente à atuação do perito contador assistente, com maior técnica e imparcialidade, expostos na estrutura e conteúdo que abarca a elaboração do seu parecer.

De outro turno, deve-se ressaltar o código de ética e conduta oriunda à profissão contábil, no caso em questão, em não aplicar conhecimentos para defender um pleito imoral ou antiético, a destacar a NBC PP 01, itens 6, 18 a 20, 23 e 24. Sá (2007) aponta, entre outros, a moral e a ética como qualidades inerentes a função do perito. 
Em tal sentido também vale citar Laurin (2013), quanto ao "único probatório", que por analogia, poderia funcionar como uma junta de instituições, tais como, Conselhos Federal e Regional de Contabilidade, além de sindicatos, parcerias com instituições de ensino, no sentido de aprimorar a fiscalização dos trabalhos, além da formação e credenciamento do perito contador assistente.

Ressalta-se a contribuição do $3^{\circ}$ entrevistado, um achado desta pesquisa, no sentido de expor que muitos profissionais que se apresentam como peritos, nomeados e assistentes, acabam migrando para a perícia exercida no Poder Judiciário, sem o devido preparo técnico e acadêmico, por não atingir êxito na sua carreira. Neste particular, a educação continuada se mostra imprescindível, bem como, os cursos de graduação, que poderiam melhor se adequar as necessidades atuais da profissão, como aponta Efiong (2012), Limongi e Miguel (2010).

As respostas são significativas contribuições para a atuação do perito contador assistente, ao apontarem aplicações práticas do processo, trazendo as competências que deve ter o perito, além da técnica necessária ao parecer técnico, inseridos no trâmite processual, complementando Sá (2007), Ornelas (2011), Neves Junior et al (2013) e Leitão Júnior et al (2012). O Quadro 7 elenca os achados da pesquisa.

Quadro 7 - Contribuições para a atuação do perito contador assistente

\begin{tabular}{|c|l|c|}
\hline Juiz & \multicolumn{1}{|c|}{ Contribuição do entrevistado } & Achados \\
\hline $2^{a}$ & Abordagem mais imparcial e técnica & $\mathrm{X}$ \\
\hline $3^{\mathrm{a}}$ e $11^{\mathrm{a}}$ & Fundamentação exposta com nexo e causalidade & $\mathrm{X}$ \\
\hline $4^{\mathrm{a}}$ & $\begin{array}{l}\text { Apresentar comparação entre o pactuado e a correta } \\
\text { aplicação técnica }\end{array}$ & $\mathrm{X}$ \\
\hline $12^{\mathrm{a}} \mathrm{e} 13^{\mathrm{a}}$ & Experiência em trabalhos processuais & $\mathrm{X}$ \\
\hline
\end{tabular}

Fonte: Elaborado pelos autores, com base na percepção dos juízes entrevistados.

A consequência da atuação eficaz do perito contador assistente resultará em um parecer que auxiliará no convencimento motivado e importante instrumento para o julgamento do conflito. $O$ afirmado pode ser corroborado com as respostas à questão 12a: Vossa Excelência já deixou de considerar o laudo do perito nomeado pelo juízo em face do conteúdo trazido em um parecer pericial de um perito contador assistente?

\section{Quadro 8 - O parecer técnico crítico em relação ao laudo pericial}

\begin{tabular}{|c|l|c|c|c|}
\hline Juiz & \multicolumn{1}{|c|}{ Resposta } & F & D & C \\
\hline $1^{a}$ & $\begin{array}{l}\text { Divergente do perito judicial, não, porque normalmente o perito } \\
\text { judicial que é imparcial os assistentes trazem mais de acordo com que } \\
\text { a parte que o contratou. O que pode acontecer é o laudo do perito } \\
\text { contador assistente ter algum argumento e mando o perito judicial } \\
\text { retificar o laudo dele pra explicar o porquê ele agiu diferente, mas } \\
\text { normalmente é com base no perito de confiança do juízo. }\end{array}$ & $X$ & \\
\hline $2^{a}$ & $\begin{array}{l}\text { Já. Já sim, já aconteceu, acabei considerando e solicitando uma } \\
\text { nova perícia. }\end{array}$ & $X$ & $X$ \\
\hline $3^{a}$ & $\begin{array}{l}\text { Como a gente falou considera, inclusive contrário, mas em matéria } \\
\text { técnica, numérica, eu não me lembro de um caso. }\end{array}$ & $X$ & \\
\hline
\end{tabular}




\begin{tabular}{|c|c|c|c|c|}
\hline $4^{a}$ & $\begin{array}{l}\text { Nunca. É difícil isso, pois quando o juiz tem um perito ele confia no } \\
\text { perito é uma relação de confiança mesmo não tem outra palavra, se } \\
\text { de repente ele começar a derrubar o laudo do perito ele troca de } \\
\text { perito. }\end{array}$ & & $\mathrm{x}$ & \\
\hline $5^{a}$ & Parcialmente já. & $\mathrm{X}$ & & \\
\hline $6^{a}$ & $\begin{array}{l}\text { Já cheguei a determinar a realização de uma segunda perícia, mas } \\
\text { não desconsiderar o laudo e considerar só o conteúdo do parecer do } \\
\text { assistente técnico. }\end{array}$ & $x$ & & \\
\hline $7^{\mathrm{a}}$ & $\begin{array}{l}\text { Eu deixei de considerar em tese, na verdade, após o parecer do } \\
\text { assistente técnico, solicitei ao perito determinados esclarecimentos } \\
\text { específicos em função de alguns apontamentos do assistente. }\end{array}$ & $x$ & & $X$ \\
\hline $8^{a}$ & $\begin{array}{l}\text { Não, mesmo porque o perito leva em consideração aquilo que o } \\
\text { assistente técnico coloca como quesito. }\end{array}$ & & $x$ & \\
\hline $9^{a}$ & Já. & & $\mathrm{X}$ & \\
\hline $10^{a}$ & Sim, eu já fiz isso. & & $\mathrm{X}$ & \\
\hline $11^{\mathrm{a}}$ & $\begin{array}{l}\text { Eu acho que eu já, eu não vou te afirmar com certeza, em relação à } \\
\text { prova contábil exatamente eu não me recordo não. Agora em } \\
\text { relação, salvo engano, já aconteceu isso em prova técnica de erro } \\
\text { médico. }\end{array}$ & & $x$ & \\
\hline $12^{\mathrm{a}}$ & $\begin{array}{l}\text { Não isso não, talvez já tenha agregado, mas afastar por completo e } \\
\text { adotar o do assistente técnico não. O que eu já fiz foi nomear outro } \\
\text { perito para fazer uma nova perícia. }\end{array}$ & $\mathrm{X}$ & & \\
\hline $13^{a}$ & $\begin{array}{l}\text { Já, já aconteceu isso. É raro de acontecer. Isso pode ser enfocado de } \\
\text { uma outra maneira, que é a realização de uma outra perícia, de uma } \\
\text { segunda perícia. Mas não me parece que seja tecnicamente } \\
\text { inadequado, ao invés de fazer uma outra perícia, estando o juízo } \\
\text { convencido, a adotar o parecer ao invés de adotar o laudo. Isso gera } \\
\text { uma carga àquela questão do ônus. [...] O juiz não está adstrito ao } \\
\text { laudo pericial, podendo formar a sua convicção com outros } \\
\text { elementos ou fatos provados nos autos. Esse artigo } 436 \text { dá plena } \\
\text { possibilidade para o juiz fundar a decisão dele muito mais no parecer } \\
\text { do que no laudo. }\end{array}$ & $\mathrm{X}$ & & $x$ \\
\hline
\end{tabular}

Fonte: Elaborado pelos autores.

O questionado aos juízes foi saber se estes já deixaram de adotar o laudo pericial elaborado pelo perito que nomearam, em detrimento de utilizar o parecer técnico produzido pelo perito contador assistente.

Sete entrevistados afirmam que já consideraram o conteúdo do parecer em detrimento do laudo pericial ou já determinaram a alteração do laudo pericial, bem como, solicitaram esclarecimentos por parte do perito nomeado ou ainda deferiram segunda perícia. Tal opinião é favorável à atuação dos peritos assistentes, apontando para a relevância desta atuação no trâmite processual, principalmente, valendo-se do estudo de Mendes (2012), quanto à necessidade do juiz se vincular à prova, para fundamentar a sua motivação e consequente julgamento.

O evidenciado pode ser corroborado com Neves Junior e Oliveira (2010) ao asseverarem que $\mathrm{o}$ perito contador assistente deve deter mais conhecimentos que o perito nomeado, para que assim se instaure 0 contraditório, na matéria técnica, de maneira que não prevaleça, exclusivamente, o ponto de vista do perito nomeado. Deste modo, o perito contador assistente contribuirá para a cognição judicial, (Watanabe, 2000), o capital jurídico (Gico Junior, 2013). Tal constatação reforça a necessidade do 
A Percepção Dos Juízes Paulistanos Acerca Da Atuação Do Perito Contador Assistente À Luz Do Código De Processo Civil

perito contador assistente buscar aprimorar os seus conhecimentos técnicos e a sua formação.

15': Com os artigos $330, \S 2^{\circ}, 472$ e $917, \S 3^{\circ}, 464, \S 2^{\circ}, 165$ ao 175 do CPC, pode-se falar em maior possibilidade e relevância para a atuação dos peritos assistentes na produção da prova e auxílio para o convencimento do juiz?

Quadro 9 - A relevância da atuação do perito contador assistente

\begin{tabular}{|c|c|c|c|c|}
\hline Juiz & Resposta & $\mathbf{F}$ & D & C \\
\hline $1^{a}$ & $\begin{array}{l}\text { Olha, pode, acho que pode, mas é o que eu te falei, o juiz nomeia o seu } \\
\text { perito de confiança que acredita que vai ser imparcial com as teses das } \\
\text { duas partes. Os assistentes técnicos na pratica defendem o interesse da } \\
\text { parte que o contratou, então às vezes ele fala alguma coisa que é } \\
\text { relevante e ai você manda mudar a perícia de acordo com o que ele } \\
\text { disse, mas se fundamentar exclusivamente no laudo de um assistente é } \\
\text { mais difícil por isso, porque ele vai defender o interesse da parte que o } \\
\text { contratou. Com relação à produção das provas eu acho que não muda } \\
\text { muito do que é hoje não, [...]. }\end{array}$ & & $X$ & \\
\hline $2^{a}$ & $\begin{array}{l}\text { Sim. [...] Então, eu acho que isso só veio para trazer mais autonomia para } \\
\text { as partes de como elas querem conduzir o processo, mas elas precisam } \\
\text { pensar sempre que no final das contas quem vai julgar é o juiz, então } \\
\text { precisa munir de maior elementos possível, elementos técnicos para que } \\
\text { ele possa julgar. [...]. }\end{array}$ & $X$ & & $X$ \\
\hline $3^{a}$ & $\begin{array}{l}\text { Volto a repetir, pra mim essas figuras vão ser muito importantes, na } \\
\text { medida em que as partes elas entendem que a economia que elas } \\
\text { acham que vão fazer não é economia é gasto, ou seja, ela precisa } \\
\text { entender que gastar com perícia é relevante para o êxito da demanda. } \\
\text { [...]. }\end{array}$ & $X$ & & $X$ \\
\hline $4^{a}$ & $\begin{array}{l}\text { Olha tudo que vier de prova que o juiz não pode fazer, que é o caso da } \\
\text { contabilidade quando exigida ou admitida, tudo que vier é lucro. A } \\
\text { questão do perito contador assistente eu não consigo fazer esse recorte } \\
\text { que você está fazendo, porque a prova uma vez nos autos ela pertence } \\
\text { ao juízo ou ao processo, mas a questão do perito contador assistente é } \\
\text { mais um elemento para o convencimento, o debate das teses, nesse } \\
\text { sentido sim. [...]. }\end{array}$ & $X$ & & $X$ \\
\hline $5^{a}$ & $\begin{array}{l}\text { Sim, nesses termos que agente conversou. Sim na medida em que as } \\
\text { partes não conciliarem e fomenta a eternização da discussão com a } \\
\text { possibilidade da produção de mais provas e mais, na verdade, com o } \\
\text { caso de poder anular a sentença, que é uma estratégia de advogado, } \\
\text { uma sentença com base na não produção de alguma prova, isso na } \\
\text { prática poderá levar a um processo mais longo. }\end{array}$ & $X$ & & \\
\hline $6^{a}$ & $\begin{array}{l}\text { Acho que sim, acho que esses artigos acabam dando mais força para a } \\
\text { atuação do assistente técnico. Eu acho que sim, acho que fortalece a } \\
\text { ideia da produção das provas como ônus da parte mesmo ao invés da } \\
\text { busca do juiz pela verdade real. }\end{array}$ & $X$ & & \\
\hline $7^{a}$ & $\begin{array}{l}\text { [...] Bom, entendido dessa forma que eu lhe disse, adotado esse } \\
\text { procedimento, eu acho que nós teríamos um ganho bastante grande, em } \\
\text { relação ao tempo do processo e a decisão final e solução do litígio. [...]. } \\
\text { Bom, na verdade o que eu enxergo é que o novo Código de Processo } \\
\text { Civil, ao invés de desjudicializar, está tentando, dentro dessa questão das } \\
\text { provas, até onde eu estudei, abrir possibilidades ao juiz de flexibilizar um } \\
\text { pouco mais a produção das provas. [...]. Então, pensando na } \\
\text { possibilidade da oralidade, pra muitos casos, acho que isso ajuda em } \\
\text { muito, porque até onde eu acompanho na arbitragem é assim que se faz. } \\
{[\ldots] \text {...]. }}\end{array}$ & $X$ & & $X$ \\
\hline
\end{tabular}




\begin{tabular}{|c|c|c|c|c|}
\hline $8^{a}$ & $\begin{array}{l}\text { Eu tenho notícia que o novo código vai colocar a conciliação como } \\
\text { primazia, eu também sou um juiz que gosto de estimular a composição, } \\
\text { mas eu não acredito que tenha que colocar a conciliação para todo e } \\
\text { qualquer hipótese irrestritamente, porque tem muito caso que não vai se } \\
\text { chegar a uma conciliação. [...] O problema é que as partes não confiam } \\
\text { muito na palavra do outro assistente eles querem a palavra do juiz, mas } \\
\text { em um acordo pode ser interessante, abreviar esse tempo despendido } \\
\text { com a perícia. Essas ferramentas contidas nesses artigos que o Senhor } \\
\text { acabou de citar, realmente, está carecendo de uma aplicação mais } \\
\text { efetiva, talvez uma atuação mais ostensiva dos peritos possa ajudar, } \\
\text { tanto ajuda o convencimento do juiz, como ajuda a fazer essa } \\
\text { conciliação e mediação, chegar nesse termo. [...]. }\end{array}$ & $x$ & & $x$ \\
\hline $9^{a}$ & $\begin{array}{l}\text { Eu não vejo em um primeiro momento que a atuação dos assistentes vá } \\
\text { de alguma forma contribuir mais do que contribui hoje, que no código } \\
\text { atual, mesmo com algumas alterações na colheita da prova, com a } \\
\text { forma de simplificação. Não vejo que isso vai contribuir a mais do que } \\
\text { contribui hoje. Eu entendo que o código, de certa forma se tornou um } \\
\text { pouco exaustivo, isso é ruim, seja na parte procedimental, mas não vejo, } \\
\text { em um primeiro momento, um desincentivo à solução extrajudicial. Eu } \\
\text { tenho pra mim que outras regras acabam comprometendo a celeridade } \\
\text { e não essas de produção das provas, mas outras sim vão acabar } \\
\text { comprometendo a celeridade do processo. }\end{array}$ & & $x$ & $x$ \\
\hline $10^{a}$ & $\begin{array}{l}\text { Havendo essa possibilidade que você citou, de que eles compareçam a } \\
\text { uma audiência de conciliação, mesmo antes, na mediação, acho que } \\
\text { vai aumentar a importância da participação deles no processo sim. Ou } \\
\text { antes, até em uma fase pré-processual. A prova é aquilo; se o juiz } \\
\text { entender que ele não está com o convencimento formado, e que ele } \\
\text { precisa da prova, ele defere a produção. [...]. Essa é a tendência. }\end{array}$ & $x$ & & $x$ \\
\hline $11^{a}$ & $\begin{array}{l}\text { Sim, pode. É. Eu acredito que talvez seja uma metodologia nova a ser } \\
\text { implementada no Brasil. Os operadores do Direito, juízes, advogados, } \\
\text { promotores, etc., que terão que se adaptar. [...], o termo correto a ser } \\
\text { utilizado; o certo seria você ter agora uma amplitude um pouco maior de } \\
\text { possibilidade probatória, desde que essa prova seja lícita e se observe o } \\
\text { contraditório e a ampla defesa para a parte contrária. }\end{array}$ & $x$ & & $x$ \\
\hline $12^{a}$ & $\begin{array}{l}\text { Em possibilidade sim, mas enfim, muitas vezes a regra prevê de uma } \\
\text { forma e a prática é de outra. Porque não basta que crie no novo código, } \\
\text { precisa existir uma prática de aplicação desse código, dessa nova lei. } \\
\text { Isso só a experiência só a aplicação em si, dos dispositivos é que vai } \\
\text { responder essa pergunta. Mas acho que há possibilidade sim. Enfim, } \\
\text { possibilidade e relevância sim. Acho que não. [...] }\end{array}$ & $x$ & & $x$ \\
\hline $13^{a}$ & $\begin{array}{l}\text { Eu acho que principalmente a prova simplificada, que é propriamente a } \\
\text { inovação, ou pelo menos uma regra que acentua a possibilidade dessa } \\
\text { simplificação, eu acho que o código incrementa a importância do } \\
\text { assistente técnico que, aliás, sempre foi importante... O assistente técnico } \\
\text { sempre foi e vai continuar sendo cada vez mais importante, no sentido de } \\
\text { levar para a parede conhecimento, que por sua vez a parte vai levar } \\
\text { para a formação da convicção do juiz. Seria muito bom se os advogados } \\
\text { atentassem mais para a preparação técnica das demandas, e não ficar } \\
\text { simplesmente fazendo alegações a respeito de assuntos que ele não } \\
\text { domina. [...]. O conhecimento deveria ser, antes de se tomar uma } \\
\text { decisão sobre ingressar ou não com uma ação, permanecer ou não com } \\
\text { uma ação, a pessoa tem que procurar se informar a respeito. [...]. }\end{array}$ & $x$ & & $x$ \\
\hline
\end{tabular}

Fonte: Elaborado pelos autores.

O CPC vigente, no momento da pesquisa em vacância, trouxe novidades, como a prova oral simplificada, artigo 464, $\S 2$, entre outros 
dispositivos que mostram intenção de privilegiar a autocomposição das partes, com a conciliação e mediação. Neste cenário, perguntou-se aos juízes que estes vislumbram maior possibilidade para a atuação do perito contador assistente em vista do referido Código.

Onze entrevistados afirmam ser relevante a atuação dos peritos assistentes para o convencimento motivado e julgamento do conflito legal, percepção favorável, corroborando com Neves Junior e Oliveira (2010), quanto ao maior conhecimento que deve ter o perito contador assistente em detrimento do perito nomeado.

Quanto ao CPC, acerca da conciliação e mediação a décima entrevista cita a importância dos peritos contadores no auxílio técnico na conciliação e mediação, ressaltando tal atuação antes e durante o processo. Este ponto de vista pode ser complementado com o que afirmam Peleias et al. (2017), quanto à figura do perito contador assistente como consultor técnico da parte que atende.

Ressalta-se a necessidade da adequada instrução processual acompanhada de provas técnicas, no sentido de buscar a verdade dos fatos, como defendido por Gobbo (2013). Neste sentido, considerando o parecer técnico do perito contador assistente apresentado na fase de instrução processual, nos procedimentos de conciliação e mediação, poderia haver a possibilidade da celeridade processual, abordada por Meneguin e Bugarin (2011) e Camelo e Pires (2010), dispensando-se a figura do perito nomeado pelo juízo.

Também se pode citar Silva (2011) que expõe o êxito obtido nas conciliações pré-processuais, quando as partes ainda não incorreram em honorários advocatícios e ainda decorreu menos tempo do instauro do conflito, não havendo o distanciamento das partes, favorecendo um acordo. Em tal perspectiva, a prova elaborada pelo perito contador assistente teria mais impacto, principalmente, ao antecipar aos litigantes o eventual desfecho da demanda, a considerar a previsibilidade jurídica, abordada por Gico Junior (2013).

\section{CONSIDERAÇÕES FINAIS}

A análise do conteúdo das entrevistas, explicitada nos resultados da pesquisa, permitiu responder à questão problema suscitada e alcançar os objetivos estabelecidos. Quanto ao artigo 330, $\S 2^{\circ}$ do CPC, em uma ótica favorável, a presença do perito contador assistente é indicada para assessorar na quantificação do argumento jurídico revisional. Em uma perspectiva desfavorável, principalmente quanto à redação do texto legal, a quantificação não necessariamente deve ser apresentada pelo perito contador assistente, de maneira que o próprio advogado pode apontar tal quantificação.

Com respeito ao artigo 472 do CPC, sob um viés favorável, o dispositivo se mostra importante como meio para o exercício do contraditório e ampla defesa, no que se refere ao caráter técnico, funcionando como instrumento que contribui para o convencimento motivado do juiz. Sob um olhar 
desfavorável, não seria oportuno invocar tal dispositivo, tão somente, com o intento de dispensar a prova pericial, na dúvida, deferida pelos juízes.

Sobre o artigo $917, \S 3^{\circ}$ do CPC, favoravelmente, para fazer valer o texto do dispositivo é necessário apontar matematicamente o excesso de execução, - que enseja na atuação do perito contador assistente. Em uma análise desfavorável, o juiz, na dúvida, deferirá a prova pericial, deixando de contar, exclusivamente, com os pareceres dos peritos assistentes das partes.

Acerca da prova simplificada, artigo 464, $\S 2^{\circ}$ do CPC, em uma perspectiva favorável, o dispositivo serviria para esclarecer mais rapidamente questões de menor complexidade ou extensão, valendo-se da oralidade empregada por um especialista, como por exemplo, um perito contador assistente. No entanto, em uma ótica desfavorável, os entrevistados, ao considerarem e fundamentarem a necessidade de haver nos autos uma prova robusta para justificar o convencimento motivado optariam por deferir a prova pericial.

Quanto à conciliação e mediação, artigos 165 ao 175 do CPC, favoravelmente, tais procedimentos se mostram importantes para desafogar 0 Judiciário, conferindo maior autonomia aos litigantes na produção de provas, o que poderia trazer maior relevância para a atuação dos peritos contadores assistentes, como assessores, auxiliando as partes em uma autocomposição e resolução do conflito. Desfavoravelmente, para haver a conciliação existe a necessidade de haver bom senso e pré-disposição das partes em ceder em algo nas tutelas pleiteadas, além do subsídio técnico que pode oferecer o perito contador assistente.

Conclui-se que é relevante e oportuno o parecer do perito contador assistente como meio de prova para o convencimento motivado do juiz e julgamento do conflito legal, além de um instrumento contundente na obtenção de uma tutela. Para os entrevistados, poderá haver maior relevância na atuação dos peritos assistentes assessorando tecnicamente as partes, os mediadores e conciliadores, ao se considerar presente a possibilidade da composição das partes com a inclusão da conciliação e mediação no Código analisado, a dispensar a figura do perito nomeado.

A partir das contribuições ofertadas pelos entrevistados, o perito contador assistente deve se conscientizar e ser responsabilizado pela importância de sua atuação, pois o CPC possibilita que este aponte o valor de uma discussão jurídica. Uma vez que o perito contador assistente apresente um parecer, este deve estar fundamentado e claro acerca dos procedimentos técnicos adotados, de maneira a ser penalizado pelos órgãos reguladores competentes, ao empregar uma postura parcial que possa gerar prejuízo para qualquer das partes litigantes. Apenas dessa forma haverá meio para a elevação e reconhecimento da profissão.

Quanto às afirmações dos entrevistados sobre parcialidade e carência por conhecimentos específicos, os juízes devem observar o currículo atualizado do perito, nomeado ou assistente, acostado ao laudo ou parecer, considerando a sua formação técnica e experiência na área, para minimizar uma visão 
generalista e de desconfiança, principalmente, quanto à atuação do perito contador assistente.

Com relação à afirmação dos entrevistados sobre a presença do perito contador assistente ser incomum no trâmite processual, atrelada à falta de recursos financeiros dos litigantes e isso prejudicar o julgamento, cabe aos órgãos competentes, sindicatos, além de parcerias com instituições de ensino, que cobram anvidades e mensalidades se engajarem e organizar meios para que haja uma mínima assistência técnica aos litigantes.

Por fim, foi possível se deparar com situações que eventualmente possam se desdobrar em problemas para pesquisas futuras ao se pensar na contribuição da atuação do perito contador assistente, tais como, (i) a triangulação desta pesquisa com a análise documental das sentenças prolatadas por juízes, (ii) a análise da aplicação técnica contida nas jurisprudências que envolvem questões financeiras, (ii) a relevância do subsídio técnico no procedimento de conciliação e mediação.

\section{REFERÊNCIAS}

BARONE, F. M.; SADER, E. Acesso ao crédito no Brasil: evolução e perspectivas. Revista de Administração Pública, Rio de Janeiro, v. 42, n. 6, p. 1249-1267, dez. 2008.

BRODY, R. G.; MELENDY, S. R.; PERRI, F. S. Commentary from the American Accounting Association's 2011 annual meeting panel on emerging issues in fraud research. Accounting Horizons, Sarasota, v. 26, n. 3, p. 513-531, Set. 2012.

CADEMARTORI, L. H. U.; BAGGENSTOSS, G. A. A coerência do sistema jurídico em Luhmann: uma proposta ao fechamento operacional e à abertura cognitiva da decisão judicial. Revista Sequência, Santa Catarina, n. 62, p. 323-359, Jul. 2011.

CAMELO, B.; PIRES, M. L. Estudo comparativo e análise econômica do direito contratual estadunidense e brasileiro. Economic Analysis of Law Review, Brasília, v. 2, n. 2, p. 321-340, Jul. 2011.

CARDOSO, M. F.; SANTOS, A. C. B.; ALLOUFA, J. M. L. Sujeito, linguagem, ideologia, mundo: técnica hermenêutico-dialética para análise de dados qualitativos de estudos críticos em Administração. Revista de Administração FACES Journal, Belo Horizonte, v. 14, n. 2, 74-93, Abr. 2015.

CERVO, A. L.; BERVIAN, P. A.; SILVA, R. Metodologia científica. 6. ed. São Paulo: Pearson Prentice Hall, 2007.

CHALMERS, K.; WRIGHT, S. Bridging accounting research and practice: a value adding endeavor. In: EVANS, E.; BURRITT, R.; GUTHRIE, J. (Org.). Bridging the gap academic accounting research and professional pratice. Sydney: The Institute of Chartered Accountants in Australia, 2011.

EFIONG, E. J. Forensic accounting education: an exploration of level of awareness in developing economies - Nigeria as a case study. International Journal of Business and Management, Toronto, v. 7, n. 4, p. 26-34, Jun. 2012. 
FONTANELLA, B. J. B.; RICAS, J.; TURATO, E. R. Amostragem por saturação em pesquisas qualitativas em saúde: contribuições teóricas, Caderno de Saúde Pública, Rio de Janeiro, v. 24, p. 17-27, jan. 2008.

GICO JUNIOR, I. T. Anarquismo judicial e teoria dos times. Economic Analysis of Law Review, Brasília, v. 4, n. 2, p. 269-294, Jul. 2013.

GOBBO, L. O. Análise econômica dos efeitos das condições da ação sobre a celeridade processual. Economic Analysis of Law Review, Brasília, v. 4, n. 2, p. 337-359, Jul. 2013.

KUSHNIROFF, M. Forensic accounting demystified. GSTF Business Review, Singapore, v. 1, n. 4, p. 19-24, Maio 2012.

LAURIN, J. E. Remmaping the path forward: toward a systemic view of forensic Science reform ande oversight. Texas Law Review, Austin, v. 91, n. 5, p. 1051-1118, Maio 2013.

LEITÃO JUNIOR, L. R. D.; SLOMSKI, V. G.; PELEIAS, I. R.; MENDONÇA, J. F. Relevância do laudo pericial contábil na tomada de decisão judicial:

percepção de um juiz. Revista de Informação Contábil, Recife, v. 6, n. 2, p. 21-39, abr. 2012.

LIMONGI, B.; MIGUEL, M. A. B.O Impacto da atividade lúdica no desempenho de alunos que cursam a disciplina "Perícia Contábil" em cursos de graduação em Contabilidade oferecidos por IES da Grande Florianópolis/SC. Revista Contabilidade Vista e Revista, Belo Horizonte, v. 21, n. 3, p. 73-1 10, jul. 2010.

LUCCAS, R. G; RELVAS, T. R. S. O contador forense na investigação e combate a fraudes no Brasil: aplicação da técnica Delphi. In: CONGRESSO USP FIPECAFI, 2013, São Paulo. Anais eletrônicos... São Paulo: FEA-USP, 2013. Disponível em: < http://www.congressousp.fipecafi.org/web/artigos 132013/662.pdf >. Acesso em: 20 fev. 2015.

MARIONI, L. G. Direito fundamental à duração razoável do processo. Revista Estação Científica (Edição Especial Direito), Juiz de Fora, v. 1, n. 4, p. 82-97, Out. 2009.

MARTINS, G. A.; THEÓPHILO, C. R. Metodologia da investigação científica para ciências sociais aplicadas. São Paulo: Atlas, 2007.

MELLO, P. C. Perícia contábil. São Paulo: Senac, 2013.

MENDES, R. L. T. Verdade real e livre convencimento: o processo decisório judicial brasileiro visto de uma perspectiva empírica. Dilemas Revista de Estudos de Conflito e Controle Social, Rio de Janeiro, v. 5, n. 3, p. 447-482, Jul. 2012.

MENEGUIN, F. B.; BUGARIN, M. S. Execução provisória da sentença: uma análise econômica do processo penal. Economic Analysis of Law Review, Brasília, v. 2, n. 2, p. 204-229, Jul. 2011.

MICHELAT, G. Sobre a utilização da entrevista não diretiva em Sociologia. In: THIOLLENT, M. Crítica metodológica, investigação social e enquete operária. São Paulo, Pólis, 1982, p. 194-212. 
MOZZATO, A. R.; GRZYBOVISKI, D. Análise de conteúdo como técnica de análise de dados qualitativos no campo da administração: potencial e desafios. Revista de Administração Contemporânea, Curitiba, v. 15, n. 4. P. 731-747, Jul.201 1.

NEVES JUNIOR, I. J.; FERREIRA, L. V.; GUIMARÃES, V.; BARRETO, M. D. et al. Conhecimentos e habilidades desejáveis aos peritos e peritos assistentes atuários. Revista Pensar Contábil, Rio de Janeiro, v. 15, n. 58, p. 44-54, set. 2013.

NEVES JUNIOR, I. J.; MELO, W. M. Perito contábil judicial: um estudo exploratório sobre a inserção do perito contador no mercado de trabalho. Revista Brasileira de Contabilidade, São Paulo, n. 185, p. 55-69, Set. 2010.

NEVES JUNIOR, I. J.; OLIVEIRA, D. S. A relevância do trabalho de perícia contábil desenvolvida por assistente técnico nas ações revisionais de contratos: uma análise documental dos processos da Caixa Econômica Federal - CEF. Revista Brasileira de Contabilidade, São Paulo, n. 184, p. 73-89, Jul. 2010.

ORNELAS, M. M. G. Perícia contábil. 5. ed. São Paulo: Atlas, 2011.

PALOMBINO, F. M. Judicial economy and limitation of the scope of the decision in international adjudication. Leiden Journal of International Law, Cambridge, $v$. 23, n. 4, p. 909-932, Dez. 2010.

PEDNEAULT, S.; SILVERSTONE, H; SHEETZ, M.; RUDEWICZ, F. Forensic accounting for non-experts. 3. ed. New Jersey: John Wiley \& Sons. Copyright. 2012.

PELEIAS, I. R.; SILVEIRA, A. G.; ORNELAS, M. M. G.; WEFFORT, E. F. J. O assistente técnico em perícias contábeis; a percepção de advogados à luz da teoria dos papéis, Revista de Arbitragem e Mediação, São Paulo, v. 52, p. 141-168, jan. 2017.

SÁ, A. L. Perícia Contábil. 7. ed. São Paulo: Atlas, 2007.

SAVOIA, J. R. F.; SAITO, A. T.; SANTANA, F. A. Paradigmas da educação financeira no Brasil. Revista de Administração Pública, Rio de Janeiro, v. 41, n. 6, p. 1121 1141 , dez. 2007.

SILVA, F. C. N. M. Conciliação cível em primeira instância em São Paulo: perspectiva da análise econômica do Direito. Economic Analysis of Law Review, Brasília, v. 2, n. 1, p. 65-94, jan. 2011.

SILVA, T. D. L.; SILVA, E. M. Mas o que é mesmo corpus? Alguns apontamentos sobre a construção de corpo de pesquisa nos estudos de Administração. In: ENCONTRO ANPAD XXXVII, 2013, Rio de Janeiro. Anais eletrônicos... Rio de Janeiro: ENANPAD, 2013. Disponível em: < http://www.anpad.org.br/admin/pdf/2013_EnANPAD_EPQ1021.pdf >. Acesso em: 14 jun. 2015.

TAVEIRA, L D. B.; MEDEIROS, A. W.; CAMARA, R. P. B.; MARTINS, J. D. M. Uma análise bibliométrica dos artigos científicos em perícia contábil publicados entre os anos de 1999 e 2012. Revista de Contabilidade do Mestrado em Ciências Contábeis da UERJ, Rio de Janeiro, v. 18, n. 2, p. 49-64, Mai. 2013.

WATANABE, K. Da cognição do processo civil. São Paulo: Bookseller, 2000.

ZANNA, R. D. Prática de perícia contábil. 3. ed. São Paulo: IOB, 2011. 